\title{
Plagues and their Function in Sources of Late Antique- Visigothic Hispania and Gregory of Tours
}

\section{Introduction}

The outbreak of plagues has been fully documented across the centuries, from the minor to the catastrophic. There are far too many to refer to, the most recent ones, Ebola, SARS in 2013, and now COVID19 are hardly anomalous. All are unique in their extension and impact; the current one has not yet run its course, but it will as they all $\mathrm{do}^{2}$. In the sources, plagues in many instances hardly ever appear in isolation, most of the time it is within the context of other events: visions, miracles, portents, and other unusual phenomenon. At times plagues appear without any comment about them being an ominous message from God or a portent of worse things to

1 Prof. Dr. Alberto Ferreiro, Professor of European History, Department of History, Seattle Pacific University, Seattle, USA; e-mail: betomicielo@gmail.com; ORCID: 0000-0001-5452-8474.

2 The notable ones are: Antonine Plague (165-180+ A.D.), Justinian plague (541542 A.D.), Roman plague (590 A.D.), Black Plague (1347+), Italian Plague (1629-1631), Plague of London (1665-1666), Marseille (1720), Spanish Influenza (1918-1920), and others. See the enlightening study by a distinguished scholar: W.H. McNeill, Plagues and Peoples, New York 1976. A fundamental book of all major outbreaks is: S. Watts, Epidemics and History: Disease, Power and Imperialism, New Haven 1999. For the early modern and modern period: J. Loomis, Epidemics: The Impact of Germs and Their Power over Humanity, Santa Barbara 2018. See the chapter for Gallia: R. Van Dam, Illness, Healing, and Relic Cults, in: Leadership and Community in Late Antique Gaul, ed. R. Van Dam, The Transformation of the Classical Heritage 8, Berkeley 1985, p. 256-276. There are many other books on pandemics and natural disasters and their impact on civilizations. 
come. The larger topic of the supernatural is one that has been the object of abundant studies spanning Late Antiquity to the late Middle Ages. In the case of Suevic - Visigothic Hispania specifically the few studies that have engaged the theme have done so unevenly ${ }^{3}$. Writers from Gallia, notable Gregory of Tours, have received more attention. The focus in this inquiry is exclusively on plagues; the broader phenomenon of the supernatural I have

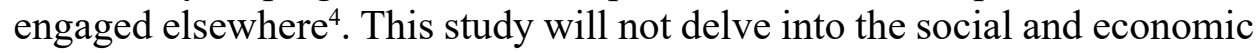
impact of plagues and pandemics ${ }^{5}$.

\section{Biblical Weltanschauung}

The Late Antique and early medieval culture of Hispania and Gallia was founded on the twin pillars of Greco-Roman and Judeo-Christian civilization, adding to this hybrid the Germanic. Of the two sources from antiquity the main one to shape the Weltanschauung of writers was the JudeoChristian. This in no way diminishes the Greco-Roman impact that left deep imprints in so many other areas of culture and society. The authors in our study explicitly made known the Judeo-Christian influence in their historical writing.

3 See J. Fernández Alonso, La cura pastoral en la España romanovisigoda, Publicaciones del Instituto Español de Estudios Eclesiásticos. Monografías 2, Roma 1955; C. García Rodríguez, El culto de los santos en la España Romana y Visigoda, Monografías de Historia Eclesiástica 1, Madrid 1966 is still one of the most important works on the topic of the cult of saints in Hispania. Consult also Santos, Obispos y Reliquias, Actas del III Encuentro Hispania en la Antigüedad Tardía. Santos, Obispos y Reliquias, Alcalá, Octubre 1998, ed. L.A. García Moreno - M.E. Gil Egea - S. Rascón Márquez - M. Vallejo Girvés, Acta Antiqua Complutensia 3, Alcalá de Henares 2003. P. Castillo Maldonado, Los mártires hispanorromanos y su culto en la Hispania de la Antigüedad Tardía, Biblioteca de Estudios Clásicos, Granada 1999 is a study on the place and role of martyrs and their shrines in Late Antique Hispania. The work of S. Castellanos, Hagiografia y Sociedad en la Hispania Visigoda. La Vita Aemiliani y el actual territorio riojano (siglo VI), Biblioteca de Temas Riojanos 103, Logroño 1999, considers the Vita Aemiliani mostly for its social and economic information.

4 See my forthcoming Divine Providence, Miracles, Demonic attacks, Portents and Visions in Suevic-Visigothic Hispania: An Overview of the Pertinent Sources, "Hagiographica".

5 For a study of the impact of natural disasters in the rural areas consult L.A. García Moreno, El Campesino Hispanovisigodo entre bajos rendimientos y catástrofes naturales. Su incidencia demográfica, in: Los visigodos. Historia y civilización, ed. A. González Blanco, Antigüedad y Cristianismo III, Murcia 1986, p. 171-187. 
Pedro Juan Galán Sánchez has summed up brilliantly the shift that happened in historical writing in the transition from pagan antiquity to Christianity, as chroniclers wrote from the perspective of the Judeo/ Christian Weltanschauung. One crucial element was Providence that is present in the Classical and Christian narratives. He informs us that antiquity created a 'scientific' historiography. "In pagan historiography on the other hand, the Divine did not intervene in historical events as in the Christian view. In Classical historiography, man was the main protagonist of events. For the Christian historian, the creator, organizer, and director of history was not humans, it was instead God. The Christian hero was now the main instrument of Divine activity. The rerum actor that was at center of human events in pagan historiography was now reconfigured to

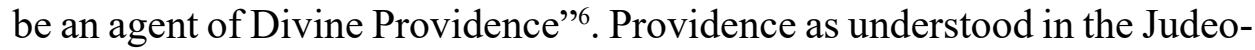
Christian tradition was a concept lacking in Classical historical narratives, if by that one means a Divine intelligence guiding history according to a preconceived plan?

All events whether the provenance was human or from nature were oftentimes interpreted as being part of the Providence of God. Plagues in our case were not coincidental, big or small, they had a role in the grand scheme of Salvation History. In the Old and New Testament the Hand of God, whether implicitly identified or hidden, is present throughout in the form of miracles and natural events. In the Gospel of John they are called 'signs'. In the Old and New Testament plagues are prominent. The Psalmist expressed lucidly the causal relationship in this case between plagues, immorality, its consequences, and God's providential intervention, "they provoked the Lord to anger with their doings, and a plague broke out among them. Then Phin'ehas stood up and interposed, and the plague was stayed" (106:29-30).

6 P.J. Galán Sánchez, El género historiográfico de la chronica. Las crónicas hispanas de época visigoda. Anejo Anuario de Estudios Filológicos 12, Cáceres 1994, p. 30-31: "Los historiadores paganos habían conseguido desprender los hechos positivos de los primitivos relatos legendarios. Habían creado la historiografía 'científica.' Por otro lado, en la historiografía pagana, la divinidad no solía intervenir en el devenir histórico. En la historiografía clásica, por tanto, el hombre es el único protagonista de los hechos [...]. Para el historiador cristiano, en cambio, el creador, organizador y director de la Historia no es tanto el hombre, sino Dios [...]. El héroe Cristiano no es sino un instrumento de la acción divina". This is an important monograph for the topic of Providence and corollary subjects in the works of Hydatius, p. 61-76; John of Biclar, p. 87-119 at 111-116; and Isidore of Seville, p. 175-208 at 190-197.

7 Galán Sánchez, El género historiográfico de la Chronica, p. 31 note 84. 
The template was set for Christian chroniclers and biblical exegetes beyond the New Testament on how natural phenomenon were interpreted, including plagues ${ }^{8}$. One need not look any further for the Old Testament than the Ten Plagues of Egypt (Exodus 7:14-12:36). The approach was to flesh out moral lessons that each plague represented and to emphasize that all of them revealed the Hand of God in human affairs ${ }^{9}$. Hydatius, John of Biclar, Isidore of Seville, the anonymous Vitas Sanctorum Patrum Emeretensium, some Visigothic councils of Toledo, and Gregory of Tours presented in their own way the deeds of human beings in Hispania and Gallia as not divorced from the designs of God just as is had been presented in the Old and New Testament. The quintessential example from the New Testament is the book of Revelation where several sets of plagues are found. The main passages about plagues commence with the three plagues unleashed by the sixth angel on the human race as punishment for their sins (9:18). This was followed later in the vision by seven final plagues (15:1-8 and 16:1$21)$. There are other places where plagues are mentioned, even outside of Revelation ${ }^{10}$. The numbers three and seven in biblical numerology denotes completeness or fullness; in this case that the full wrath of God has been justly let loose on a rebellious world.

All human deeds are mysteriously under the guidance of the Hand of God that at times may be hidden from human sight. It was actually intended to be comforting to those who wanted to make sense of what seemed on the

8 For a collection of patristic exegesis of these passages and more refer to the Ancient Christian Commentary on Scripture, Old Testament, v. 3: Exodus, Leviticus, Numbers, Deuteronomy, ed. J.T. Lienhard, Downers Grove 2001, p. 43-67.

9 Examples of the moral lessons derived from the plagues can be found in the sermons of Caesarius of Arles who also reproduced some by Augustine, an English translation is in Caesarius of Arles, Sermons, vol. 2 (81-186), tr. M.M. Mueller, The Fathers of the Church 47, Washington 1964. The Latin edition is in Caesarii Arelatensis, Sermones, ed. G. Morin, CCL 103, Turnhout 1953. Caesarius Arelatensis, Sermo 99, p. 403-406 = Mueller, p. 81-85; Sermo 100, p. 406-413 by Augustine and 100A, p. 413-416= Mueller, p. 85-98; this one on Pharaoh is relevant, Sermon 101, p. 416-420= Mueller, p. 98-103; another on the Ten Plagues by Augustine is Sermo 122, p. 509-511= Mueller, p. 203-206. For patristic exegesis, Ancient Christian Commentary on Scripture, New Testament, v. 12: Revelation, ed. W.C. Weinrich, Downers Grove 2005, p. 237-244, 244-264.

10 Additional passages in Revelation are $6: 7-8 ; 11: 6 ; 16: 9 ; 18: 4,8$ and in the Gospel of Luke 21:11. For the patristic exegesis of the Revelation passages see, Weinrich, Revelation, p. 161-162, 252-253, 288-292, there are more citations throughout the volume. For the Luke passage see: Ancient Christian Commentary on Scripture, New Testament, v. 3: Luke, ed. A.A. Just Jr., Downers Grove 2003, p. 319-320. 
surface pointless tragedies. In a pre-scientific world that had no knowledge of bacteria, viruses, empirical scientific laws of nature, it was logical that people turned to the spiritual or to deities to find meaning and hope. It is not being argued here that in our time of science, reason, and abundant technological feats that faith in God is obsolete. On the contrary, belief in the supernatural or God is held by the majority of the human race. So, it is not surprising that in the current COVID 19 pandemic as in all of the modern era pandemics many people still seek meaning and solace in religious faith, as they did in the pre-modern eras.

The exegetical approach of our writers when they addressed plagues and any other calamities, manmade or natural, was rooted in the biblical model. The literal was not the most important aspect of scripture, it was the allegorical/typological/moral meaning of the events that was the central one, they contain eternal values. Caesarius of Arles and Isidore of Seville expressed it best. Caesarius in Sermon 99 on the Ten Plagues taught after he had expounded on the moral lessons of each one, "Therefore, let us rejoice and thank God, clearly beloved, because through His mercy these things which we read happened at that time in figures and images we both feel and see have been fulfilled in us [...]"11. On the plagues, Isidore noted, "Then the plagues are visited upon Egypt. They were carried out corporally among the Egyptians; they are now carried out spiritually in us, for Egypt is the figure of this world"12. Plagues were interpreted in the same manner, from the literal to the allegorical to reveal the spiritual and moral message. Our writers in their own style saw themselves as a continuation of the Eusebius' Chronica, Chronicon of Jerome, Orosius and other predecessors and contemporaries. They did not draw sharp distinctions in terms of historical events between the Old and New Testament eras and what followed in the post-apostolic period, it was to them an organic unity until the Second Advent of Christ. The stages of history in the Christian scheme were divided into seven epochs that form a seamless whole.

11 "Haec ergo, fratres carissimi, quae illo tempore per figuras et imagines legimus facta, gaudeamus et gratias deo agamus quia in nobis per eius misericordiam et sentimus et videmus esse conpleta" (Caesarius Arelatensis, Sermo 99, CCL 103, p. 406, tr. Mueller, p. 85).

12 Isidorius Hispalensis, Mysticorum expositiones Sacramentorum seu quaestiones in Vetus Testamentum, In Exodum XIV, De decem plagis 1, PL 83, 292: "Dehinc inferuntur plagae in Aegyptum. Licet illa in Aegyptiis corporaliter gesta sunt, spiritualiter tamen nunc geruntur in nobis. Aegyptus namque saeculi forma est". See also Lienhard, Exodus, Leviticus, Numbers, Deuteronomy, p. 44. 


\section{Hydatius}

In the case of Hydatius, Julio Campos identified this main feature, "He has followed the use of the Chronica of Jerome for the most part and the dating of Abraham, Olympiads, imperial years; furthermore those of Christ, vulgar history or Dionysian". Hydatius conceived the historical events in his chronicle, secular and sacred, as mysteriously unfolding side by side as proposed in Augustine's City of God as an essential part of Salvation History ${ }^{13}$.

Four entries in the Chronicle of Hydatius recorded the effects of plagues and accompanying calamities that afflicted the province of Gallaecia. Hydatius did not hesitate to venture into what their meaning was within the designs of the Providence of God. The first documented that an intense pestilence generated devastation. To add to the misery, wild barbarians plundered cities throughout Hispania stealing food and resources, even tax collectors and dishonest soldiers were singled out for misdeeds. If that were not enough a famine drove many people to cannibalism, they ate the victims of pestilence, famine, and the sword. Wild beasts had their fill from the bodies of the dead. The four-fold plagues of sword, famine, pestilence, and wild animals Hydatius said had been foretold by the Lord's prophets. What prophets Hydatius had in mind, he did not divulge! The one biblical verse that lists fourfold calamities is in Revelation 6:8 when the fourth seal was opened, it unleashed the pale rider of Death and Hades "to kill with the sword and with famine and with pestilence and by wild beasts of the earth" a fourth of the earth. Pestilence and the accompanying calamities were seen collectively but mysteriously part of God's plan for Hispania ${ }^{14}$.

13 Cronicon de Idacio, Obispo de Chaves (s. IV-V), ed. and tr. J. Campos, Salamanca 1984, p. 21 (The edition is based on the Theodore Mommsen MGH text): "Ha seguido el uso de la Crónica de Jerónimo en gran parte que data por los de Abraham, por las Olimpiadas, por años imperatorios y además por los de Cristo o era vulgar o Dionisiana”. See the in-depth discussion on these dating issues in: The Chronicle of Hydatius and the Consularia Constatinopolitana. Two Contemporary Accounts of the Final Years of the Roman Empire, ed. R.W. Burgess, Oxford 1993, p. 27-46.

14 "Barbari qui in Hispanias ingressi fuerant caede depredantur hostili. Pestilentia suas partes non segnius operatur. Debaccantibus per Hispanias barbaris et seuiente nihilominus pestilentiae malo opes et conditam in urbibus substantiam tyrannicus exactor diripit et milites exauriunt. Fames dira crassatur adeo ut humanae carnes ab humano genere ui famis fuerint deuoratae; matres quoque necatis uel coctis per se natorum suorum sint paste corporibus; bestie, occisorum gladio fame pestilentia cadaueribus adsuaetae, quosque hominum fortiores interimunt eorumque carnibus paste passim in humani generis efferantur 
In the second, Hydatius mentioned specifically the intervention of God. After much destruction, man-made or by pestilence, the Lord out of compassion swayed the hearts of the barbarians to pursue peace. Hydatius then described where each barbarian tribe established their own kingdom and how the Hispano-Romans submitted to them as the new rulers. As a result of God's intervention not only did the plunder cease but also the pestilence that had accompanied $\mathrm{it}^{15}$. In the third, a comet appeared in December and was visible for several months. More importantly, it was an omen that disaster was imminent in the form of a plague that was to descend on the entire world ${ }^{16}$. The final incident described the Huns' rampage in Italy, disease and calamities accompanied Divine retribution. It happened in the second year of the princeps Marcian. The Huns were also afflicted with heaven sent famine and disease. Human agency as instrument of God's punishment was meted out as auxiliaries sent by the Emperor Marcian under the leadership of Aetius, who along with the aforementioned disasters and the soldiers of Marcian, crushed the Huns. The Huns sued for peace with the Romans and departed to their homeland where Attila died on the way ${ }^{17}$. This account reads right out of the pages of the Old Testament as concerns the view that all human activity and in nature were guided by God to accomplish the intended purpose. Hydatius among Christian chroniclers

interitum. Et ita quatuor plagis ferri famis pestilentie bestiarum ubique in toto orbe seuientibus, predicte a domino per prophetas suos adnuntiationes implentur" (Hydatius Lemicus, Continvatio Chronicorvm Hieronymianorvm 16, Burgess, p. 82-83; Campos, p. 56-59).

15 "Subuersis memorata plagarum crassatione Hispaniae prouinciis barbari ad pacem ineundam domino miserante conuersi, sorte ad inhabitandum sibi prouinciarum diuidunt regiones. Calliciam Vandali occupant et Suaeui sitam in extremitate Oceani maris occidua. Alani Lusitaniam et Carthaginiensem prouincias et Vandali cognomine Silingi Beticam sortiuntur. Spani per ciuitates et castella residui a plagis barbarorum per prouincias dominantium se subiciunt seruituti" (Hydatius Lemicus, Continvatio Chronicorvm Hieronymianorvm 17, Burgess, p. 82-83; Campos, p. 58-59).

16 "Cometae sidus apparere incipit mense Decembri; quod per menses aliquot uisum subsequentis in pestilentia plagae, quae fere in toto orbe diffusa est, praemisit ostentum" (Hydatius Lemicus, Continvatio Chronicorvm Hieronymianorvm 18, Burgess, p. 96-97; Campos, p. 84-85).

17 "SECVNDO regni anno principis Martiani Vni qui Italiam praedabantur, aliquantis etiam ciuitatibus inruptis, diuinitus partim fame, partim morbo quodam plagis caelestibus feriuntur. Missis etiam per Martianum principem Aetio duce caeduntur auxiliis pariterque in sedibus suis et caelestibus plagis et per Marciani subiguntur exercitum, et ita subacti pace facta cum Romanis proprias uniuersi repetunt sedes; ad quas rex eorum Attala mox reuersus interiit" (Hydatius Lemicus, Continvatio Chronicorvm Hieronymianorvm 29, Burgess, p. 102-103; Campos, p. 96-97). 
was hardly exceptional in this approach to writing history; he was very much mainstream.

\section{John of Biclar}

One of the early editors of John of Biclar, Pablo Álvarez Rubiano had this to say about the Chronicon: "The Chronica of Biclaro came to be a continuation of the universal chronicle of saint Jerome"18. The work did not incorporate biblical dating much less beginning at Creation, the dates of Roman/Byzantine emperors and those of the barbarian kings, notably Visigoths are the signposts of the work. The apogee of the Chronicon is the Third Council of Toledo (589) where King Reccared abjured Arianism.

Three entries of the Chronicon are of interest for the aims of this study on plagues. Firstly, in the imperial city of Constantinople death spread as a result of bubonic plague. John lamented that many thousands of men died. No explicit statement was made that the tragedy was caused by God; his observation was as a human observer passing no judgement on whether it was Divine punishment ${ }^{19}$. The succeeding one informed that in the first day of Caesar Tiberius (Emperor Justin) the bubonic plague began to dissipate. Once again in this concise observation there was no recourse by John to connect it with Divine Providence ${ }^{20}$. In the third and last entry the reference to plague was appealed to differently; the term plague was invoked to condemn the Arian heresy by describing it as such. The context is in the section that celebrated the triumph of the Catholic faith over Arianism under King Reccared where he publicly renounced Arianism at the Third Council of Toledo (589). At the council Arianism was called-perfidia, and

18 P. Álvarez Rubiano, La Crónica de Juan Biclarense. Versión castellana y notas para su estudio, "Analecta Sacra Tarraconensia” 16 (1943) p. 7-44 at 12: "La Crónica del Biclarense, que viene a ser una continuación de la Crónica Universal de San Jerónimo". See also Juan de Biclaro. Obispo de Gerona. Su Vida y su Obra, ed. J. Campos, CSIC: Escuela de Estudios Medievales, Estudios 32, Madrid 1960, p. 56-68. For a detailed discussion of John of Biclar's text see: Iohannes Biclarensis, Chronicon, CCL 173A, ed. C. Cardelle de Hartmann - R. Collins, Turnhout 2001, p. 129-143.

19 "In regia urbe mortalitas inguinalis plage exardescit, in qua multa milia hominum uidimus defecisse" (Iohannes Biclarensis, Chronicon 26, CCL 173A, p. 65; Campos, Juan de Biclaro 7, 4, p. 83; Álvarez Rubiano, 7, 4, p. 26).

20 "Huius Tiberii Caesaris die prima in regia urbe inguinalis plaga sedata est" (Iohannes Biclarensis, Chronicon 33, CCL 173A, p. 66; Campos, Juan de Biclaro, 8, 4, p. 84; Álvarez Rubiano, 8, 4, p. 28). 
infestatione ${ }^{21}$. The full text of the Chronicon about the council, the lengthy acts of the Toledan council, and the homily of Leander of Seville reveal explicitly that the extirpation of the heresy in Hispania was a direct act of $\mathrm{God}^{22}$. This was as close John came to acknowledging the intervention of God in human affairs. The Chronicon overall is the most secular of the chronicles in this survey. I do believe that the last entry, the longest sustained commentary, reveals to my mind that the entire Chronicon in John's view was providentially in God's hands. All events leading up to the most important Toledo council caused the permanent defeat of Arianism and triumph of the Catholic faith.

\section{Isidore of Seville}

Isidore of Seville wrote two historical texts that are different from each other in structure. One of them, the Chronica resembles that of Hydatius and John of Biclar; unlike theirs it begins with Creation and ends in $615 \mathrm{AD}^{23}$. The second is the History of the Goths, Vandals, and Suevi about which the editors Guido Donini and Gordon B. Ford, Jr. insightfully remarked, "Isidore's principal sources for this History of the Goths were the contin-

21 "Que post hec non solum orientis et occidentis partem maculauit, sed etiam meridianam et septentrionis plagam et ipsas insulas sua perfidia irrethiuit [...] huius haeresis infestatione laborauit" (Iohannes Biclarensis, Chronicon 91, CCL 173A, p. 82; Campos, Juan de Biclaro, 8, 1, p. 98-99; Álvarez Rubiano, 24, 1, p. 40).

22 Consult the articles of Alberto Ferreiro on the council and the homily: Quia pax et caritas facta est: Unity and Peace in Leander's Homily at the Third Council of Toledo (589), “Annuarium Historiae Conciliorum" 48 (2016-2017) p. 87-108; A. Ferreiro, Sanctissimus idem princeps sic venerandum concilium ad loquitur dicens: King Reccared's Discourses at the Third Council of Toledo (589), "Annuarium Historiae Conciliorum" 46 (2014) p. 27-52; A. Ferreiro, Secundum quod sancta synodus: Advancing the Mission of the Church through Conciliar Legislation after the Third Council of Toledo (589), "Annuarium Historiae Conciliorum" 44 (2012) p. 27-46; A. Ferreiro, The Theology and Typology of the Third Council of Toledo (589), "Annuarium Historiae Conciliorum" 40 (2008) p. 61-84; A. Ferreiro, Linguarum diversitate: 'Babel and Pentecost' in Leander's homily at the Third Council of Toledo, in: XIV Centenario del Concilio III de Toledo 5891989. Toledo 10-14, Mayo, ed. Arzobispado de Toledo, Toledo 1991, p. 237-248.

23 Isidorius Hispalensis, Chronica, ed. J.C. Martín Iglesias, CCL 112, Turnhout 2003, tr. K.B. Wolf, 'Chronicon,' Isidore of Seville, c. 616, in: Claremont Colleges Scholarship@ Claremont Pomona Faculty Publications and Research Pomona Faculty Scholarship 1-1-2008, in: https://scholarship.claremont.edu/pomona_fac_pub/45/(access: 10.12.2020). 
uation of Eusebius' Chronica by Jerome to the year 378". Additionally, Isidore availed himself of Orosius, Hydatius, Victor of Tununa, Prosper of Aquitaine, John of Biclar, and the lost chronicle of Bishop Maximus of Zaragoza. The Hand of God was dutifully identified by Isidore in several key passages in the form of direct intervention and retribution that among other afflictions included plagues ${ }^{24}$.

There are only four references to plagues in Isidore's Historia Gothorum, Vandalorum et Suevorum that are illustrative of God's involvement. In all of them Isidore borrowed mainly from Hydatius and other writers ${ }^{25}$. Before moving into the entries it is essential to note that often in the chronicles it was believed that a causal relationship existed between natural disasters and the pagan or heretical beliefs of the barbarians. Another layer to this worldview is that natural or human calamities were part of the plan of God. We even witness the coupling of the misdeeds of barbarian invaders with accompanying plagues and famines in a letter from Braulio of Zaragoza to his good friend Isidore of Seville. After Braulio apologized for not writing earlier to him, he said "I have been prevented from making my demands by a terrible invasion - not only the evil of famine and poverty, but also by that of pestilence and the presence of the enemy"26.

In the Historia in chapter twenty-seven a combination of heavenly intervention and natural portents as signs from God unmistakably was voiced by Isidore. The object of God's ire were the notorious Huns whose lead-

24 Isidore of Seville, History of the Goths, Vandals, and Suevi, tr. G. Donini G.B. Ford Jr., Leiden 1970, p. VII-VIII.

25 All of Isidore's borrowings from other writers are conveniently found in: Las Historias de los Godos, Vandalos y Suevos de Isidoro de Sevilla, ed. and tr. C. Rodríguez Alonso, Colección Fuentes y Estudios de Historia Leonesa 13, León 1975, p. 69-102.

26 "O pie domne et uirorum praestantissime, sera est inquisitio et tarde data mihi scribendi optio, quia peccatis meis ingruentibus non modo sterilitatis uel inopie malo uerum etiam luis et hostilitatis quominus inquirerem orribili sum praepeditus incursu" (Braulionus Caesaraugustanus, Epistula 2 (3), tr. L. Riesco Terrero, Epistolario de San Braulio, Anales de la Universidad Hispalense. Filosofía y Letras 31, Sevilla 1975, p. 6465). In the editions of Riesco Terrero and Barlow it is numbered as Letter 3, in Miguel Franco and Martín-Iglesias it is Letter 2. See Bravlionis Caesaravgvstani, Confessio vel Professio Ivdaeorvm Civitatis Toletanae, CCL 114 B, ed. R. Miguel Franco - J.C. MartínIglesias, Turnhout 2018, p. 4. For the English translation see: C.W. Barlow, Braulio of Saragossa, Fructuosus of Braga, Iberian Fathers 2 - The Fathers of the Church 63, Washington 1969, p. 17. See the new Spanish edition in: Braulio de Zaragoza, Epístolas, ed. and tr. R. Miguel Franco, Akal/Clásicos Latinos Medievales y Renacentistas 30, Madrid 2015. 
er Attila was later given the byname "Scourge of God" (Flagellum Dei) Isidore related a battle where they were cut down by heaven sent plagues and routed by the Emperor Marcian in a pitched battle ${ }^{27}$. God utilized natural portents and the military skills of Marcian to punish the wicked pagan Huns. In the second example at chapter seventy-two Isidore recounted that when the pagan tribes of the Vandals, Sueves, and Alans invaded and occupied Hispania, famine, pestilence, cannibalism, and violence came upon them in fourfold plagues that lay waste the land as predicted by the prophets [again anonymous]. They were clear signs that expressed God's anger and justice that punished human evil sometimes with natural disasters ${ }^{28}$. The third entry is chapter seventy-three where the effects of plagues were mentioned twice. Isidore opened by solemnly lamenting that in the era 449 (411) after the destruction of Hispania precipitated by plagues, through the mercy of God the barbarians sued for peace with each other and proceeded to divide the provinces to settle into. The destruction of the barbarians and the plagues were two-fold events mysteriously under the Hand of God. Isidore further remarked that the Spani (Hispano-Romans) that remained in the cities and fortresses, after being victimized by the plague, submitted to the barbarians as the new rulers. God did not in this instance come to the rescue $^{29}$. At the end of the chapter the wrath of God came into full display on the pagan barbarians. The incident pitted the Christian relics at a shrine in Seville against the faithless barbarians. It happened that Gunderic, a Vandal King, after he laid waste to Seville, determined to attack the church of the renowned martyr Vincent. His fiendish sacrilege was thwarted by God at the gate of the shrine by allowing a demon to seize him where he died on the $\operatorname{spot}^{30}$. The justice of God was in full display for all to see.

27 "Qui et ibi partim fame, partim caelestibus plagis percussi interierunt" (Isidorius Hispalensis, Historia Gothorum, Wandalorum, Sueborum 27, Rodríguez Alonso, p. 214217; Donini and Ford, p. 14).

28 "Ita quattuor plagis per omnem Spaniam saeuientibus diuinae iracundiae per prophetas scripta olim praenuntiatio adinpletur" (Isidorius Hispalensis, Historia Gothorum, Wandalorum, Sueborum 72, Rodríguez Alonso, p. 290-291; Donini and Ford, p. 33-34).

29 “Aera CCCCXLVIIII post plagarum diram perniciem quibus Spania caesa est, tandem barbari pacem ineundam deo miserante conuersi sorte in possessionem sibi eius prouincias diuidunt [...]. Spani autem per ciuitates et castella residua plagis adflicti barbarorum dominantium sese seruituti subiciunt [...]" (Isidorius Hispalensis, Historia Gothorum, Wandalorum, Sueborum 73, Rodríguez Alonso, p. 290-293; Donini and Ford, p. 34).

30 "Qui cum auctoritat regiae potestatis inreuerentes manus in basilicam Vincentii martyris ciuitatis ipsius in extendisset, mox dei iudicio in foribus templi daemonio cor- 
Chapter seventy-five, the last entry, the focus was on the Vandals, enemies for the most part of the Catholic faith. Plague appears not as a literal disease afflicting the body. This is how it played out. King Gunderic made matters worse in his realm when he introduced Arianism in North Africa; it resulted in the exile of many Catholic priests, the martyrdom of many, and the transfer of Catholic churches to the Arians. Arianism was called a pestilence - Arrianam pestilentiam; from that we can infer of the worst form, it could precipitate the eternal destruction of the soul. A far greater affliction than killing the body. The Catholic faith is the medicine to heal the soul from this pestilence. The reader was informed that it was a fulfillment of a prophecy foretold by Daniel. It is not possible to find a direct link to the book of Daniel ${ }^{31}$. Referring to heresy as a pestilence is one many negative labels used by the Church Fathers to highlight its danger to the faithful. A noteworthy difference with the text is that Hydatius called Arianism only an impious heresy - impietatem. All of Isidore's entries containing plagues unequivocally linked them to God's providential plan.

\section{Vitas Sanctorum Patrum Emeretensium}

The text that is the only source strictly speaking a hagiography originating from Hispania is the anonymous Vitas Sanctorum Patrum Emeretensium (VSPE). It is, however, the second hagiography used in this study, the other is the De virtutibus sancti Martini of Gregory of Tours. In the VSPE there are a pair of incidents involving the main protagonist Bishop Masona of Mérida and a plague. One of the eminent editors of the VSPE was Joseph N. Garvin who had this to say about the text, "The VPE is a hagiographical document, since its author's ultimate aim was the spiritual improvement of his readers and since its content is for the most part happenings wherein God's Providence is displayed". This

reptus interiit" (Isidorius Hispalensis, Historia Gothorum, Wandalorum, Sueborum 73, Rodríguez Alonso, p. 292-293; Donini and Ford, p. 34).

31 "Arrianam pestilentiam per totam Africam intromittit, sacerdotes ecclesiis pellit, martyres plurimos efficit et iuxta prophetiam Danielis demutatis mysteriis sanctorum ecclesias Christi hostibus tradidit nec iam diuini cultus loca sed suorum esse habitacula iussit" (Isidorius Hispalensis, Historia Gothorum, Wandalorum, Sueborum 75, Rodríquez Alonso, p. 295-297; Donini and Ford, p. 35). The information was adopted by Isidore from Hydatius (Burgess, p. 94; Campos, p. 82-83). 
observation about the main purpose of a hagiography goes to the core purpose of the text ${ }^{32}$.

Two incidents contain the main protagonist Bishop Masona of Mérida, the shrine of the renowned martyr Eulalia of Mérida, and the struggle against Arianism in the context of numerous calamities inflicting the city and province. In the first, Bishop Masona went to the basilica of Eulalia to plead for her intervention to drive away numerous maladies inflicting Mérida - disease, plague, and famine. All of them were driven away from Mérida through their joint intercession. Lastly, countless healings were reported at the tombs of the Fathers of Mérida who were buried close to the altar of the holy martyr Eulalia ${ }^{33}$. At this time Mérida was the most important city of Hispania for spiritual, economic, and political reasons. Add to that, it was a major pilgrimage destination that popularized the cult of Eulalia in Hispania ${ }^{34}$. In a second intervention, Eulalia on behalf of Masona castigated with great pain the Arian King Leovigild who persecuted and exiled the bishop. Leovigild fearing greater torments, ordered that Masona be allowed to return from exile to Mérida. Eulalia had threatened the king with death if he continued to delay Masona's return. Nepopis, the Arian appointee of Leovigild, fled the city when he heard that Masona was returning. He did not want to be present to see the triumphant Masona and suffer public humiliation or worse. After Masona arrived at Mérida, thanks

32 See Vitas Sanctorum Patrum Emeretensium, ed. and tr. J.N. Garvin, Studies in Medieval and Renaissance Latin Language and Literature 19, Washington 1946, p. 26.

33 "Dilectus namque Deo et hominibus, etate et gloria mirabilis, amator fratrum, multum orans pro populo, cuius nomen multis choruscando miraculis per omnem terra pertransibit. Huius itaque temporibus morbum pestem inedieque inopiam ab urbe Emerentensi uel omnem Lusitaniam eius precibus Dominus procul abegit meritisque sacresancte Eolalie uirginis longius pepulit" (Vitas Sanctorum Patrum Emeretensium V 2, CCL 116, p. 48-49; Garvin, p. 190-191; Lives of the Visigothic Fathers, tr. A.T. Fear, Translated Texts for Historians 26, Liverpool 1997, p. 37).

34 "Horum igitur supradictorum sanctorum corpora in una eademque cellula aud procul ab altario sanctissime uirginis Eolalie honorifice tumulata quiescunt. Ad quorum denique ueneranda sepulcra tantam Xpus quottidie copiose pietatis confert gratiam, ut quacumque fuerit quispiam egritudine conuexatus, quocumque etiam fuerit languore afflictus, statim ut diuinum nomen illic toto corde deposcerit, omnes a se morbos discussos omnesque maculas pulsas diuinitus sentiens sanus ylarisque ad cupitam per Dei gratiam peruenit sanitatem" (Vitas Sanctorum Patrum Emeretensium V 15, CCL 116, p. 101; Garvin, p. 256-259; Fear, p. 104). See the fundamental study on pilgrimage with many references to Hispania: M. Dietz, Wandering Monks, Virgins, and Pilgrims. Ascetic Travel in the Mediterranean World, A.D. 300-800, University Park, Pennsylvania 2005. 
to the interventions of the martyr Eulalia, it ended famine, plague, and great storms that tormented the city and province ${ }^{35}$.

\section{Visigothic Councils of Toledo}

Plagues and pestilence appear under differing circumstances in six councils that convened in Toledo ${ }^{36}$. Arianism was the central focal point at the Third Council of Toledo (589) and it is there that the founder of the heresy Arius was called a pestilence - fidei pestem Arrium citing the Council of Nicaea (325) where 318 bishops condemned him. Isidore of Seville we observed earlier had done the same regarding the Arian heresy, calling it Arrianam pestilentiam $^{37}$. It is worth pointing out that disease as an image of heresy was another negative label used sometimes by the Church Fathers. Epiphanius of Salamis after all named his famous heresiology the Panarion -medicine chest. At the Fourth Council of Toledo (633) in canon 75 the bishops warned about the consequences of sinning against the king. It is a lengthy exposition of examples of how God punished people who sinned against God's anointed. The example given was David when he was tempted to kill King Saul, God's appointed king; David spared his life twice (1 Samuel 24:1$22 ; 26: 1-25)$. The warning was self-evident; there were serious consequences

35 "Tum deinde, nulla intercurrente mora, prefata gloriosa uirgo iniurias serui sui seuerissima uindicauit ultione. Denique nocte quadam recubanti in stratu suo impio Leouigildo tiranno adstitit eique flagris diu multumque utraque latera uerberauit dicens: Redde mici seruum meum. Nam si moram feceris ad reddendum, scito te acrioribus suppliciis excruciandum, [...] Ipse uidelicet Nepopis infeliciter ab omni clero uel populo pulsus ab Emerita ad suam ciuitatem festinus perrexit ac, ne eum uir Dei Masona in sua eclesia inuenisset et cum omni ignominia pelleret [...]. Reddita sunt a Domino Emeretensi eclesie copiosa suffragia, nam calamitatum penurias et crebras pestilentie clades insolentesque totius urbis procellas sancti uir presentia Domino miserante suspendit, quas indubie remoto pastore causa eius absentie pressit" (Vitas Sanctorum Patrum Emeretensium V 8, CCL 116, p. 74, 76, and 78; Garvin, p. 222-225, 226-227, 228-229; Fear, p. 88-91).

36 Concilios Visigóticos e Hispano-Romanos, ed. J. Vives - T. Marín Martínez - G. Martínez Díez, España Cristiana. Textos 1, Barcelona - Madrid 1963: Council of Toledo III (589), p. 112, Council of Toledo IV (633), p. 218, Council of Toledo VIII (653), p. 266, 269, Council of Toledo XII (681), p. 380, 381, 382, 383, Council of Toledo XVI (693), p. 484, 515, Council of Toledo XVII (694), p. 525.

37 " [...] et in laudem fidem sanctam Nicaeni observe et honoro concilii, quam contra eundem rectae fidei pestem Arrium trecentorum decem et octo sancta episcopalis scripsit synodus" (Concilium Toletanum III, Vives, p. 112). 
for regicide no matter how justified it might seem. The same condemnation is found in John of Biclar and Isidore of Seville concerning the usurper Catholic Hermenegild against his Arian father King Leovigild; the son was described as a tyrant and usurper ${ }^{38}$. The plague here under these circumstances was interpreted as punishment from God ${ }^{39}$. Twice at the Eighth Council of Toledo (653) in the reign of King Reccesvinth the bishops invoked pestilence to condemn the customs and way of life of the Jews and rebellious slaves that fomented social unrest. Together they were a threat to the social and spiritual order of society ${ }^{40}$. Below we witness under King Egica how Jews were mentioned again but in a different situation. In the Twelfth Council of Toledo (681) in the opening remarks the bishops referred to plagues twice that could be terminated by being faithful to sacred things. In the second, plague/pestilence/contagion was used to refer to disease of the body and soul that the sacrament could cleanse ${ }^{41}$. There are two other passages in this council where pestilence was harnessed to deal with particular issues. In the first instance, Egica appealed to the bishops to help him cleanse the realm of the contagion of all manner of evil practices polluting society. Among them the king singled out the faith of the Jews that he said fostered insane novelties that should be extirpated at its roots. The second reference dealt with an entirely different topic; the king endorsed a law previously issued by King Sisebut that castigated men who avoided military conscription or deserted. Egica called it a pestilent infamy ${ }^{42}$. At the Sixteenth Council of Toledo (693) the

38 See my forthcoming: Visigoths, Sueves, Vandals, and Alans: Shifting Attitudes about Barbarians in Sources of Late Antique Hispania and Gregory of Tours, in: Visigoths, Goths, and Early Medieval Barbarians in Popular Culture, Visigothic Symposium 5, Networks \& Neighbors.

39 "Unde et nos cavere oportet casum huiusmodi gentium, ne similiter plaga feriamur praecipiti et poena puniamur crudeli" (Concilium Toletanum IV 75, Vives, p. 218).

40 " [...] iudaeorum scilicet et vitam moresque denuntio, quorum tantummodo novi terram regiminis mei pollutam esse peste contagii" (Concilium Toletanum VIII, Vives, p. 266). "[...] adeo ut cabtivorum turmas reducere et desolationes terrae quae tali concurssae sunt pesti quilibet conatus nequeat reparare" (Concilium Toletanum VIII 2, Vives, p. 269).

41 "Et ideo quibus malis terra prematur quibusque plagis proventu dierum succedentium feriatur, paternitate vestrae non reor esse incognitum [...] per vos salvationis obtineat lucrum per quos regenerationis percipit sacramentum, ut diligentia definitionis vestrae ab omni emundata contagio et ab infirmitatis peste sit libera et bonorum omnium sit proventibus gratiosa" (Concilium Toletanum XII, Vives, p. 380, 381).

42 “[...] quod plus his omnibus est, iudaeorum pestem quae in novam semper recrudescit insaniam radicitus extirpate [...] vicis peste huius infamationis" (Concilium Toletanum XII, Vives, p. 382, 383). 
first mention of plagues is in the speech to the bishops by King Egica where he unmistakably said that they were produced by God's ire. In a second reference at the same council it was lamented that the bishops of the Narbonne province were unable to attend because of a plague; it was not identified this time as any kind of punishment from $\mathrm{God}^{43}$. At the Seventeenth Council of Toledo (694) in the address of King Egica he mentioned plague when he talked about the Jews living in Gallia Narbonensis. The canon is in the context of the repressive measure passed by Egica to deal with would be usurpers and other conspirators, above all Jews. The suspicious Jewish conversos from Gallia Narbonensis were not blamed for the plague and other calamities at this point. The repression promulgated by Egica against Jews was one of the most severe antisemitic legislation of its kind in Visigothic Hispania. Still the plague mentioned does not appear as a causal result of infidelity to the king on the part of Jews or Gentiles ${ }^{44}$.

\section{Gregory of Tours}

The first text from Gregory of Tours that requires additional preliminary commentary because of its complexity, literary genre, and voluminosity comes from the Libri historiarvm decem. Gregory did not adopt the approach of the chronicles of Hydatius, John of Biclar, and Isidore's Chronica. His is not a series of pithy few sentences much like headlines in a news outlet or text messages. Gregory instead created sustained detailed narratives; he was a serious storyteller. Gregory of Tours had in common with our other writers in that he too used previous chroniclers. Lewis Thorpe identified the key sources and biblical foundation of Gregory's

43 "Quantis denique malis indignante Deo terra cotidie vapulet quantisque plagis vel perfidorum sceleribus contabescat [...]. Et quia ingruente inguinalis plaguae vastatione ad Narbonensem sedem pertinentes episcopi nequaquam sunt in hac sancta synodo adgregati" (Concilium Toletanum XVI, Vives, p. 484, 515). See J. Orlandis - D. Ramos-Lissón, Historia de los Concilios de la España Romana y Visigoda, Pamplona 1986, p. 494-495.

44 "Illis tantumdem hebraeis ad presens reservatis, qui Galliae provinciae videlicet infra clausuras noscuntur habitatores existere vel ad ducatum regionis ipsius pertinere, ut quia delictis ingruentibus et externae gentis incursu et plagae inguinalis interitu pars ipsa ab hominibus desolata dinoscitur, cum omnibus rebus suis in suffragio ducis terrae ipsius existant et publicis utilitatibus profectum incunctanter exhibeant, ita ut secundam sanctae fidei regulam ut verae christicolae vitam suam corrigant, et omnem genuinae incredulitas errorem a suis cordibus pellant" (Concilium Toletanum XVII, Vives, p. 525). Full commentary is in: Orlandis - Ramos-Lissón, Historia de los Concilios, p. 502-505. 
work, "Inspired by his reading of the chronicles of Eusebius, Saint Jerome and Orosius, and by his knowledge of the Bible, Gregory took upon himself the task of prefixing to the narrative of his own times the Old Testament story from the days of the Creation onwards, then the Nativity of Christ and then later events in the New Testament" 45 . The 'prefixing to the narrative' comment by Thorpe needs to be unpacked; it was more than just a passing prefix. There was something deeper that Gregory was intent to accomplish. Book 1 consigned what followed in that same chapter in the post-apostolic period to the end of Book 10 within the course of Salvation History. These were not just the deeds of people carrying on of their own volition irrespective of Divine oversight. Everything to the smallest detail transpired under the mysterious Hand of God; it was at times identified openly by Gregory. When he did not explicitly say so, the reader could rest assured that God's will was nevertheless unfolding.

In Book 1 Gregory included the death of St. Martin of Tours, whose cult he enthusiastically promoted. Thorpe took notice that in just chapter one Gregory, "had covered in one Book of thirty-five chapters no fewer than 5596 years of world history" ${ }^{4}$. Book 1 can be broken down as follows: Chapters 1-24 from Creation to Ascension of Jesus/deaths of Pilate and Herod. Chapters 25-48 from Passions of Peter and Paul/Nero to death of Martin of Tours. Chapters 26-29, other apostles, martyrs, and early Church Fathers. Chapter 30 concentrated on the Church in Gaul. Gregory, moreover, in Book 1 did not create a hard break between the Old and New Testament era and the post-apostolic one, it was perceived as a seamless flow of events that revealed God's hand over Gaul, its peoples, and cultures that eventually converted to Christianity. In the last entry of the Libri historiarvm decem in Book 10, chapter 31, Gregory offered a brief chronology of five epochs of what he covered; he said it was a total of 5792 years, it adds up actually to 6063 years.

Of the two plagues, one occurred in Visigothic Hispania and Narbonne. Although one of them took place in Merovingian Gallia it involved the Suevic King Miro of Gallaecia and his legates whose return home was delayed by the epidemic and political machinations against them while they were on the way to visit King Guntram. It has been included here since the main protagonists were from Hispania. As they travelled, they passed through Poitiers province then ruled by King Chilperic. He arrested them

45 Gregory of Tours, History of the Franks, tr. L. Thorpe, London - New York 1974, p. 25.

46 Gregory of Tours, History of the Franks, p. 25. 
and locked them in prison in Paris. Gregory recorded that unusual portents happened: a wolf appeared at the gates of Poitiers, the heavens were aflame, the rivers Cher and Loire overflowed causing floods, high winds triggered widespread damage, cocks unusually crowed as night arrived, the moon darkened, a comet was seen, and a major epidemic spread among the people. After a year when the calamities passed the Suevic king and legates were allowed to return to Gallaecia ${ }^{47}$.

When King Chilperic's ambassadors returned home from Spain after meeting with the monarchy in Toledo, they reported that Carpetania in the district of Toledo had been devastated by swarms of locusts. Gregory interjected that the enmity between King Leovigild and his son had intensified. Of importance is that the father was Arian and his son Hermenegild was the Catholic usurper who sought to overthrow him. Gregory seemed to be establishing a causal link between that dispute with the calamities that befell the district of Toledo where the Visigothic capital was located and the Narbonne that was part of the Visigothic kingdom. A severe plague ravaged the region districts but most especially in the city of Narbonne. The people who fled returned only to be struck by the disease again, what we call today a 'second wave'. The plague endured for three years and then suddenly died out. The city of Albi, too, suffered greatly from the same epidemic. Lastly, in the sky several unusual phenomena were witnessed adding to the uncertainty and fear already upsetting the people ${ }^{48}$.

47 "Mirus rex Galliciensis legatos ad Guntchramnum regem dirixit. Cumque per Pectavum terminum praeterirent, quod tunc Chilpericus rex tenebat, nuntitata sunt ei. At ille sub custodia sibi eos exhibere praecepit et Parisius custodire [...] Gravis autem lues in populo subsecuta est. Legati autem Sueborum post annum demissi, ad propria redierunt" (Gregorius Turonensis, Libri historiarum decem V 41, Scriptores Rervm Merovingicarvm I 1, ed. B. Krusch - W. Levison, MGH, Hannover 1951, p. 248; Thorpe, Gregory of Tours, p. 305-306).

48 "Legati principis Chilperici de Hispaniis regressi, nuntiaverunt, provintiam Carpitaniam graviter a locustis fuisse vastatam [...]. Agebant enim, inimicitias illas, quae inter Leuvichildum et filium suum pullulaverant, vehementer augere. Per loca enim lues vastabat, sed maximae apud urbem Narbonensim validius desaeviebat, et iam tertio anno, quod ibidem adpraehenderat et requieverat; populique revertentes a fuga, iterum morbo consumpti sunt. Nam et Albigensis civitas maximae ab hoc inquomodo laborabat" (Gregorius Turonensis, Libri historiarum decem VI 33, SRM I 1, p. 304, Thorpe, p. 363-364). Other plagues that broke out in Gallia recorded in the Libri historiarvm decem are: IV 31, p. 163-166; V 23, p. 230; VI 14, 44, p. 283-284, 316-317; VIII 12 , p. 378-379; X 23, 30, p. 514-515, 525. References are from the Scriptores Rerum Merovingicarvm I, 1 edition. 
The second example from Gregory's writings that spoke of plague in Hispania in the region of Gallaecia is in his celebrated hagiography De virtutibus sancti Martini at book 1, chapter $11^{49}$. It is a singular account with details about the conversion of the Sueves to the Catholic faith out of Arianism not recorded elsewhere. Gregory's account, however, does not concur in the least with Isidore's version on how they converted. The minutiae have been engaged elsewhere ${ }^{50}$. What is of interest is the reference to a contagion of leprosy that devastated Gallaecia.

The conversion unfolded in the reign of Chararic, king of the Sueves in Gallaecia. It was he who constructed the first church in Braga in honor of Martin of Tours in gratitude for the healing of his son through his relics at Tours ${ }^{51}$. Here are the main contours of what Gregory recounted. Chararic was an Arian who sought a cure for his son that was on his deathbed. Having heard about the miracles at the Martinian shrine in Tours, he dispatched some legates to invoke the saint at his tomb. Chararic's Arianism prevented the healing; he realized that he had to abandon Arianism to procure the healing. He proceeded to erect the church to Martin to house a relic of the saint. The legates were dispatched a second time with larger gifts for the shrine at Tours. This time the son was healed; more than that happened

49 For Gregory's account of a plague in Gallaecia in the kingdom of the Sueves see: Gregorii Episcopi Tvronensis, De virtutibus sancti Martini, Scriptores Rervm Merovingicarvm I 2, ed. B. Krusch, MGH, Hannover 1969, p. 594-596 = Martini Episcopi Bracarensis Opera Omnia, ed. C.W. Barlow, Papers and Monographs of the American Academy in Rome 12, New Haven - Yale 1950, p. 298-300. An English translation is in: R. Van Dam, Saints and Their Miracles in Late Antique Gaul, Princeton 1993, p. 211-213.

50 An in-depth study of this text that explained and resolved the discrepancies between Gregory and Isidore is in: A. Ferreiro, Braga and Tours: Some observations on Gregory's De virtutibus sancti Martini (1.11), JECS 3/2 (1995) p. 195-210. The article is mainly a response to Edward A. Thompson who saw no possibility of reconciling the two versions, he opined that "the narratives of Gregory and Isidore run on parallel lines which do not meet even if produced to infinity". See E.A. Thompson, The Conversion of the Spanish Suevi to Catholicism, in: Visigothic Spain: New Approaches, ed. E. James, Oxford 1980, p. 77-92.

51 Ferreiro, Braga and Tours, p. 195-210. For issues surrounding the first foundation of a church to Martin of Tours at Gallaecia in Hispania, consult: A. Ferreiro, The First Introduction of the Cult of St. Martin of Tours in Gallaecia in Late Antiquity: Portucale, Auriense, or Dumium/Bracara Augusta?, in: San Martín de Tours y su proyección en la Gallaecia de época Sueva. Congreso Internacional del Nacimiento de San Martín de Tours (316-2016), Patrón de Ourense, 14-18 de noviembre de 2016. Power, Conversion, Religious Leadership and the Christianization of the Landscape in Late Antiquity and the Early Middle Ages, BAR International, Oxford, (forthcoming). 
throughout Gallaecia. Gregory added that prisoners were set free as the relics were taken to the new church, a plague of leprosy that had desolated Gallaecia was vanquished along with many other illnesses. The contagion of leprosy never returned again, so Gregory reported. It seems that the leprosy was punishment inflicted on the king's son and the people of Gallaecia for professing Arianism. The problem was resolved by abjuring Arianism and appealing to the intercession of Martin of Tours, whom Gregory once again lauded for his successful anti-Arianism. The intervention of God was plain for all to see and Martin of Tours became an important source of healing. The advent of the cult of Santiago in Compostela abetted, not diminished, devotion to Martin of Tours throughout all of Hispania in the Middle Ages $^{52}$.

\section{Conclusion}

Plagues and human deeds were presented not divorced from the purpose of God, similar to the Old and New Testament. Plagues in the rarest of instances were not exhibited apart from a moral message and the Providence of God. In the majority of the examples, plagues, famines, and abnormal natural phenomena were associated causally with the incursions of the barbarian tribes who wreaked havoc on the local population. God, on the other hand, either directly or through a holy person ended the plagues and invasions. This approach to interpret plagues was encouraged by the Weltanschauung of the Bible. It was a way to find hope and solace in the midst of tragedy in whatever form it happened. Any event that took place in life, from the smallest to the biggest did not escape the notice of God. Plagues, therefore, accomplished God's will in the short and long term, even if it was not understood in real time.

52 A. Ferreiro, The Cult of Saints and Divine Patronage in Gallaecia before Santiago, in: The Pilgrimage to Compostela in the Middle Ages, ed. M.J. Dunn - L. Davidson, New York 1996, p. 3-22; A. Ferreiro, Martinian Veneration in Gaul and Iberia: Martin of Tours and Martin of Braga, "Studia Monastica" 51 (2009) p. 7-21; A. Ferreiro, Veneration of Martin of Tours and Martin of Braga in Northern Portugal, "Acta Historica et Archaeologica Mediaevalia" 20-21 (1999-2000) p. 223-242; A. Ferreiro, Martíno de Braga: de apóstolo dos Suevos á súa memoria en época medieval na Diocése de Mondoñedo-Ferrol, in: Galicia fai dous mil anos. O Feito Diferencial Galego. I. Historia. Santiago de Compostela, 16-19 Decembro, 1996, ed. G. Pereira Menaut, Museo do Pobo Galego, Santiago de Compostela 1997, p. 323-356. 
Plagues also served the purpose to call people to a higher moral life; it was a reminder that immorality could unleash bodily and spiritual damage, even natural disasters.

\section{Plagues and their Function in Sources of Late Antique-Visigothic Hispania and Gregory of Tours}

(summary)

This study identifies where plagues are mentioned in the works of major chroniclers of Late Antique/Visigothic Hispania; they are Hydatius, John of Biclar, Isidore of Seville, the anonymous Vitas Sanctorum Patrum Emeretensium, and select Visigothic councils of Toledo. Gregory of Tours' De virtutibus sancti Martini $(1,11)$ is the representative text of an event in Gallaecia. Two other texts in the Libri historiarum decem involve Hispania and Visigothic Narbonne. In addition a few select sermons of Caesarius of Arles have some relevance. The biblical background is explored as it relates to plagues since it shaped more than any other cultural source the Weltanschauung of our writers. The topic is timely in view of the current situation that the world is in with Covid19; even though it is hardly the first time we have been here and for sure will not be the last as the historical record shows.

Keywords: Plague; Hydatius; Isidore of Seville; John of Biclar; Gregory of Tours; Caesarius of Arles; Vitas Sanctorum Patrum Emeretensium; Visigothic Councils of Toledo

\section{Bibliography}

\section{Sources}

Braulionus Caesaraugustanus, Epistulae, in: Braulionus Caesaraugustanus, Confessio vel Professio Ivdaeorvm Civitatis Toletanae, ed. R. Miguel Franco - J.C. Martín-Iglesias, CCL 114 B, Turnhout 2018; Epistolario de San Braulio, ed. and tr. L. Riesco Terrero, Anales de la Universidad Hispalense. Filosofía y Letras 31, Sevilla 1975; Braulio de Zaragoza, Epístolas, ed. and tr. R. Miguel Franco, Akal/Clásicos Latinos Medievales y Renacentistas 30, Madrid 2015; Braulio of Saragossa, Fructuosus of Braga, tr. C.W. Barlow, Iberian Fathers 2, The Fathers of the Church 63, Washington 1969.

Caesarius Arelatensis, Sermones, ed. G. Morin, CCL 103, Turnhout 1953; Caesarius of Arles, Sermons, vol. 2 (81-186), tr. M.M. Mueller, The Fathers of the Church 47, Washington 1964.

Concilios Visigóticos e Hispano-Romanos, ed. J. Vives - T. Marín Martínez - G. Martínez

Díez, España Cristiana. Textos 1, Barcelona - Madrid 1963. 
Gregorius Turonensis, De virtutibus sancti Martini, Scriptores Rervm Merovingicarvm I 2, ed. B. Krusch, MGH, Hannover 1969, tr. R. Van Dam, Saints and Their Miracles in Late Antique Gaul, Princeton 1993, p. 211-213.

Gregorius Turonensis, Libri historiarum decem, Scriptores Rervm Merovingicarvm I 1, ed. B. Krusch - W. Levison, MGH, Hannover 1951, tr. L. Thorpe, Gregory of Tours, History of the Franks, London - New York 1974.

Hydatius Lemicus, Continuatio Chronicorum Hieronymianorum, The Chronicle of Hydatius and the Consularia Constatinopolitana. Two Contemporary Accounts of the Final Years of the Roman Empire, ed. R.W. Burgess, Oxford 1993, ed. and tr. J. Campos, Cronicon de Idacio, Obispo de Chaves (s. IV-V), Salamanca 1984.

Iohannes Biclarensis, Chronicon, ed. C. Cardelle de Hartmann - R. Collins, CCL 173A, Turnhout 2001; Juan de Biclaro. Obispo de Gerona. Su Vida y su Obra, ed. J. Campos, CSIC. Escuela de Estudios Medievales. Estudios 32, Madrid 1960; P. Álvarez Rubiano, La Crónica de Juan Biclarense. Versión castellana y notas para su estudio, "Analecta Sacra Tarraconensia" 16 (1943) p. 7-44.

Isidorius Hispalensis, Historia Gothorum, Wandalorum, Sueborum, in: Isidore of Seville, History of the Goths, Vandals, and Suevi, tr. G. Donini - G.B. Ford Jr., Leiden 1970; Las Historias de los Godos, Vandalos y Suevos de Isidoro de Sevilla, ed. and tr. C. Rodríguez Alonso, Colección Fuentes y Estudios de Historia Leonesa 13, León 1975.

Isidorius Hispalensis, Chronica, ed. J.C. Martín Iglesias, CCL 112, Turnhout 2003, tr. K.B. Wolf, 'Chronicon,' Isidore of Seville, c. 616, in: Claremont Colleges Scholarship@Claremont Pomona Faculty Publications and Research Pomona Faculty Scholarship 1-1-2008, in: https://scholarship.claremont.edu/pomona_fac_pub/45/ (access: 10.12.2020).

Isidorius Hispalensis, Mysticorum expositiones Sacramentorum seu quaestiones in Vetus Testamentum, PL 83, 207-0424D.

Martini Episcopi Bracarensis Opera Omnia, ed. C.W. Barlow, Papers and Monographs of the American Academy in Rome 12, New Haven 1950.

Vitas sanctorum Patrum Emeretensium, ed. A. Maya Sánchez, CCL 116, Brepols 1992, ed. and tr. J.N. Garvin, The Vitas Sanctorum Patrum Emeretensium, Studies in Medieval and Renaissance Latin Language and Literature 19, Washington 1946; Lives of the Visigothic Fathers, tr. A.T. Fear, Translated Texts for Historians 26, Liverpool 1997.

\section{Literature}

Ancient Christian Commentary on Scripture, New Testament, v. 12: Revelation, ed. W.C. Weinrich, Downers Grove 2005.

Ancient Christian Commentary on Scripture, New Testament, v. 3: Luke, ed. A.A. Just Jr., Downers Grove 2003.

Ancient Christian Commentary on Scripture, Old Testament, v. 3: Exodus, Leviticus, Numbers, Deuteronomy, ed. J.T. Lienhard, Downers Grove 2001. 
Castellanos S., Hagiografía y Sociedad en la Hispania Visigoda. La Vita Aemiliani y el actual territorio riojano (siglo VI), Biblioteca de Temas Riojanos, 103, Logroño 1999.

Castillo Maldonado P., Los mártires hispanorromanos y su culto en la Hispania de la Antigüedad Tardía, Biblioteca de Estudios Clásicos, Granada 1999.

Dietz M., Wandering Monks, Virgins, and Pilgrims. Ascetic Travel in the Mediterranean World, A.D. 300-800, University Park, Pennsylvania 2005.

Fernández Alonso J., La cura pastoral en la España romanovisigoda, Publicaciones del Instituto Español de Estudios Eclesiásticos, sección: monografías 2, Roma 1955.

Ferreiro A., Braga and Tours: Some observations on Gregory's De virtutibus sancti Martini (1.11), "Journal of Early Christian Studies” 3/2 (1995) p. 195-210.

Ferreiro A., Divine Providence, Miracles, Demonic attacks, Portents and Visions in Suevic-Visigothic Hispania: An Overview of the Pertinent Sources, "Hagiographica" (forthcoming).

Ferreiro A., Martinian Veneration in Gaul and Iberia: Martin of Tours and Martin of Braga, "Studia Monastica" 51 (2009) p. 7-21.

Ferreiro A., Martíño de Braga: de apóstolo dos Suevos á súa memoria en época medieval na Diocése de Mondoñedo-Ferrol, in: Galicia fai dous mil anos. O Feito Diferencial Galego. I. Historia. Santiago de Compostela, 16-19 Decembro, 1996. Museo de Pobo Galego, Santiago de Compostela 1997, p. 323-356.

Ferreiro A., Quia pax et caritas facta est: Unity and Peace in Leander's Homily at the Third Council of Toledo (589), “Annuarium Historiae Conciliorum” 48 (2016-2017) p. $87-108$.

Ferreiro A., Sanctissimus idem princeps sic venerandum concilium ad loquitur dicens: King Reccared's Discourses at the Third Council of Toledo (589), “Annuarium Historiae Conciliorum" 46 (2014) p. 27-52.

Ferreiro A., Secundum quod sancta synodus: Advancing the Mission of the Church through Conciliar Legislation after the Third Council of Toledo (589), "Annuarium Historiae Conciliorum" 44 (2012) p. 27-46.

Ferreiro A., The Cult of Saints and Divine Patronage in Gallaecia before Santiago, in: The Pilgrimage to Compostela in the Middle Ages, ed. M.J. Dunn - L. Davidson, New York 1996, p. 3-22.

Ferreiro A., The First Introduction of the Cult of St. Martin of Tours in Gallaecia in Late Antiquity: Portucale, Auriense, or Dumium/Bracara Augusta?, in: San Martín de Tours y su proyección en la Gallaecia de época Sueva. Congreso Internacional del Nacimiento de San Martín de Tours (316-2016), Patrón de Ourense, 14-18 de noviembre de 2016. Power, Conversion, Religious Leadership and the Christianization of the Landscape in Late Antiquity and the Early Middle Ages, BAR International, Oxford (forthcoming).

Ferreiro A., The Theology and Typology of the Third Council of Toledo (589), "Annuarium Historiae Conciliorum" 40 (2008) p. 61-84. 
Ferreiro A., Veneration of Martin of Tours and Martin of Braga in Northern Portugal, “Acta Historica et Archaeologica Mediaevalia” 20-21 (1999-2000) p. 223-242.

Ferreiro A., Visigoths, Sueves, Vandals, and Alans: Shifting Attitudes about Barbarians in Sources of Late Antique Hispania and Gregory of Tours, in: Visigoths, Goths, and Early Medieval Barbarians in Popular Culture, Visigothic Symposium 5, Networks \& Neighbors (forthcoming).

Galán Sánchez P.J., El género historiográfico de la chronica. Las crónicas hispanas de época visigoda, Anejo Anuario de Estudios Filológicos 12, Cáceres 1994.

García Moreno L.A., El Campesino Hispanovisigodo entre bajos rendimientos y catástrofes naturales. Su incidencia demográfica, in: Los visigodos. Historia y civilización, ed. A. González Blanco, Antigüedad y Cristianismo III, Murcia 1986, p. 171-187.

García Rodríguez C., El culto de los santos en la España Romana y Visigoda, Monografías de Historia Eclesiástica 1, Madrid 1966.

Loomis J., Epidemics: The Impact of Germs and Their Power over Humanity, Santa Barbara 2018.

McNeill W.H., Plagues and Peoples, New York 1976.

Orlandis J. - Ramos-Lissón D., Historia de los Concilios de la España Romana y Visigoda, Pamplona 1986.

Santos, Obispos y Reliquias, Actas del III Encuentro Hispania en la Antigüedad Tardía. Santos, Obispos y Reliquias. Alcalá, Octubre 1998, ed. L.A. García Moreno M.E. Gil Egea - S. Rascón Márquez - M. Vallejo Girvés, Acta Antiqua Complutensia 3, Alcalá de Henares 2003.

Thompson E.A., The Conversion of the Spanish Suevi to Catholicism, in: Visigothic Spain: New Approaches, ed. E. James, Oxford 1980, p. 77-92.

Van Dam R., Leadership and Community in Late Antique Gaul, The Transformation of the Classical Heritage 8, Berkeley 1985.

Watts S., Epidemics and History: Disease, Power and Imperialism, New Haven 1999. 